\title{
British withdrawal from CERN again a growing possibility
}

\section{London}

BRITISH scientists working at the European Organisation for Nuclear Research (CERN) have formed a group to lobby the media, industry and politicians because of growing concern that Britain will pull out of the venture. The ten-man CERN United Kingdom working party, chaired by Dr Eifionydd Jones, says that withdrawal from CERN would be "an act of scientific vandalism". The group is preparing to launch a concerted campaign to impress upon science policy-makers and industry the existing and potential importance of CERN. The working party argues that compared with many of the other member states, Britain's science community benefits to a proportionally greater extent, and that accessibility to CERN's facilities "acts as a plug to the brain drain". The group is also concerned with the apparent indifference towards CERN shown by British industry, whose failure to bid competitively for high-technology contracts is seen as one reason why Britain's future with CERN is uncertain.

Britain's continuing collaboration was put in doubt with the publication in 1985 of a report by a panel chaired by Sir John Kendrew that recommended that the United Kingdom should remain a member of CERN until 1989, but should continue its membership beyond that time only if it could be achieved at a significantly lower cost. It recommended progressive reduc- tions in subscriptions of about 5 per cent in 1988-89, rising to a total of 25 per cent in 1991-92. The report was endorsed by the Science and Engineering Research Council (SERC) and the Advisory Board for the Research Councils. In 1985-86, Britain's contribution was $£ 37.9$ million. This increased to $£ 55$ million in $1986-87$ because of a sharp fall in the value of the pound against the Swiss franc, the currency in which the contributions from all 14 member states is assessed. In response to the Kendrew report, Britain proposed, in February 1986, a seven-man international CERN review committee, which was set up under the chairmanship of Professor A. Abragam. The review committee will make an interim report to the CERN council committee on 18 June, when it will present its principal findings. It is unclear whether the committee of the council will act on any of the preliminary recommendations, or wait for the review committee's final report in December. It is felt that the latter is more likely. But given that Britain requested the interim report, it is possible that a decision on Britain's future could be taken on the basis of the findings presented in June.

Under the rules for withdrawal, Britain would have to give notice before the end of the year if it wished to pull out before 1989. How long CERN council will take in deciding whether to act on any recommendations, and whether any action

\section{British semiconductor company enters Japan's back door}

\section{London}

While most of the major US and European semiconductor manufacturers are doing battle with the Japanese, claiming trade malpractice through dumping and demanding greater access to the Japanese market, Inmos, the small British chip company, is selling its products in abundance to Japan.

Such is the group's success in Japan that a new company, Inmos Japan KK, has been formed to exploit what it considers to be an expanding market because of interest shown in the Inmos transputer, a revolutionary microchip design concentrating memory, computational power and communication links on one device.

The international arm of Japan's telecommunications network, KDD (Kokusai Denshin Denwa), has launched the first of the country's designs based on the Inmos device, an image-processing system, developed in conjunction with the imageprocessing equipment manufacturer
Kashiwagi Laboratories.

Japanese interest in the transputer has given hope to Inmos, formed in the late 1970 s with government funds to spearhead Britian's entry into a new semiconductor age, that it could break even in this coming year. The group, which has an arm in Colorado Springs in the United States and two in Newport in Wales, has been dogged with controversy, and financial problems. The project consumed more than $£ 65$ million in government funds and loans since it began and it was sold, in the autumn of 1984 , to the British electronics group Thorn-EMI for $£ 95$ million.

The group then had to attempt to survive one of the worst recessions in the global semiconductor market. The group has been rationalized, retaining a development and design presence in the United States and about 400 people, and design and management expertise in Bristol and manufacturing in Newport.

Bill Johnstone taken will satisfy the British government is not known. It is generally felt that the level of reductions recommended by the Kendrew committee is unrealistic if CERN's scientific capability is not to be severely affected. Apart from the feeling within the physics community that Britain's withdrawal would be in itself detrimental, observers argue that it would destroy Britain's credibility as a serious international collaborator, something, they say, it can ill afford, particularly as it is seeking European partners for such projects as the ISIS pulsed-neutron facility in Oxfordshire. Simon Hadlington

\section{US companies unite on chip}

Washington \& Tokyo

THE United States is to imitate Japan with an industry-wide, government-supported cooperative project to win back the world lead in semiconductor chip production. Japanese companies, long the top suppliers of standard memory chips, overtook the United States in total semiconductor sales last year.

Cooperative research projects, involving companies that usually compete, have been organized in Japan by the Ministry of International Trade and Industry (MITI), and have greatly helped Japanese companies to refine manufacturing techniques. But until recently they have been more than US companies could contemplate. Now, a coalition of US semiconductor companies, materials companies, equipment manufacturers and universities have got together to develop advanced semiconductor production equipment. The 'Sematech' project's aim is not to design new chips, an area in which US companies are still unsurpassed, but to do just as the Japanese did and refine manufacturing processes so that the maximum yield of defect-free chips can be gained.

Financial backing for the project, at $\$ 250$ million a year, is being sought in equal parts from industry and from government. Appropriations for Sematech are already included in the Department of Defense's 1988 budget proposals, now on their way through Congress. Charles Sprock, president of the National Semiconductor Corporation, who is leading the project, said he believed the United States could draw level with Japan in five years and "regain the lead soon after".

In Japan the formation of Sematech has been welcomed. "Playing Japan's game" and producing goods of high enough quality and low enough price to sell in Japan is seen as a very welcome alternative to a trade war that denies foreign markets to Japanese products.

Alun Anderson \& David Swinbanks 